\section{CardioRenal Medicine}

\title{
Improved Identification and Antihypertension Pharmacotherapy in Cardiorenal Metabolic Syndrome: Focus on Racial/Ethnic Minorities, Olmesartan Medoxomil, and Combination Therapy
}

\author{
Keith C. Ferdinand \\ Tulane School of Medicine, Tulane Heart and Vascular Institute, New Orleans, La., USA
}

\begin{abstract}
Key Words
Cardiorenal metabolic syndrome $\cdot$ Cardiovascular risk factors $\cdot$ Clinical evidence $\cdot$

Combination therapy $\cdot$ Hypertension $\cdot$ Racial/ethnic minorities
\end{abstract}

\begin{abstract}
Cardiorenal metabolic syndrome (CRS) is a global health care concern in view of aging in certain populations, increased obesity, changing lifestyles, and its close association with type 2 diabetes mellitus and cardiovascular morbidity and mortality. Determining the appropriate criteria for CRS has been somewhat controversial, and efforts to fully describe and define the syndrome are still ongoing. Nonetheless, improving knowledge of the syndrome among health care professionals will help to identify patients who may require pharmacological and therapeutic lifestyle intervention, particularly with regards to addressing high-normal blood pressure and hypertension. This article reviews current clinical guidelines with a focus on the identification, especially in racial/ethnic minorities, treatment, and associated cardiovascular morbidity and mortality of high blood pressure and hypertension in patients with CRS. Efficacy and outcomes studies that provide insight into the selection of an initial antihypertensive regimen in this population will be discussed. Finally, a brief review of the benefits of olmesartan medoxomil and combination therapy and patient factors in the management of hypertension with CRS will be addressed.




\section{CardioRenal Medicine}

\begin{tabular}{l|l}
\hline Cardiorenal Med 2012;2:256-267 \\
\hline DOI: 10.1159/000342968 \\
Published online: October 26, 2012 & $\begin{array}{l}\text { ○ 2012 S. Karger AG, Basel } \\
\text { www.karger.com/crm }\end{array}$ \\
\hline Ferdinand et al.: Emerging Concepts in Hypertension and Metabolic Syndrome
\end{tabular}

\section{Introduction}

Cardiorenal metabolic syndrome (CRS) is a collection of closely related cardiovascular $(\mathrm{CV})$ risk factors that includes elevated blood pressure (BP), dyslipidemia, obesity, and insulin resistance, and differs from the metabolic syndrome (MetS) in that it additionally includes chronic kidney disease (CKD), i.e. microalbuminuria/proteinuria or low glomerular filtration rate (GFR), in the cluster of factors defining MetS $[1,2]$. Consequently, much of our current understanding and clinical data pertaining to MetS is also applicable to CRS as the definition of CRS is fundamentally the same as that of MetS, with the addition of a renal component. Moreover, there is a higher prevalence of microalbuminuria in individuals with MetS and, therefore, many of these patients would likely be classified as having CRS. According to 20032006 data from the National Health and Nutrition Examination Survey (NHANES), the ageadjusted prevalence of MetS is 35.1\% in men and 32.6\% in women [3]. The prevalence of CRS/ MetS is increasing due to an aging population, population growth, increasing obesity rates, and sedentary lifestyles [4-6]. Along with its increasing prevalence, the association of CRS with type 2 diabetes mellitus (T2DM), CKD [7], and CV disease (CVD) has led CRS to become a prominent public health and clinical concern. Moreover, although there has been a decrease in major risk factors in many countries resulting in reduced CV mortality, body weight and diabetes have continued to increase in contrast to other risk factors such as cholesterol, smoking, and hypertension [8]. The European Prospective Investigation into Cancer and Nutrition (EPIC)-Potsdam study showed that patients with MetS have a 4.5-fold increased risk of developing T2DM. Furthermore, a meta-analysis by Mottillo et al. [6] demonstrated that patients with MetS had a 2-fold increase in the risk of CVD, CVD mortality, myocardial infarction (MI), and stroke, and a 1.5-fold increase in the risk of all-cause mortality [9]. No race-/ethnicity-specific data were reported in either meta-analysis, and the predictive value of the diagnosis of CRS across various populations needs further elucidation. Coronary heart disease (CHD) and stroke are not only leading causes of death in the United States, but also account for the largest proportion of inequality in life expectancy between whites and blacks, despite the existence of low-cost, highly effective preventive treatment, and the contribution of conventionally defined CRS may be underestimated in African-Americans [10]. Moreover, the prevalence of hypertension, a major modifiable risk factor for CVD and stroke, is much higher for non-Hispanic blacks compared with whites (42 vs. $28.8 \%$ ) in the United States [11]. Similar to hypertension, the prevalence of CKD is also higher among non-Hispanic blacks (19.9\%) than non-Hispanic whites (16.1\%) [12].

\section{MetS/CRS Definitions and Diagnosis}

While there has been disagreement regarding the appropriate terminology and diagnostic criteria for MetS/CRS, there has been some consensus that MetS/CRS is appropriate to describe a patient having several risk factors for CVD and diabetes [4]. In addition, several organizations have attempted to clarify and define MetS/CRS, including the World Health Organization (WHO), the Third Report of the National Cholesterol Education Program Adult Treatment Panel (NCEP ATP III), the International Diabetes Federation (IDF), and the American Heart Association (AHA) (WHO, NCEP ATP III, IDF, and AHA utilize the terminology MetS). Table 1 presents the diagnostic criteria of MetS as it has evolved over time. In clinical practice today, the NCEP ATP III and the IDF definitions of MetS are the most widely used for diagnosis [13].

The first recognized definition of MetS/CRS was developed by the WHO in 1998 to address the clinical need to classify the large number of patients who are at high risk for mac- 


\section{CardioRenal Medicine}

\begin{tabular}{l|l}
\hline Cardiorenal Med 2012;2:256-267 \\
\hline DOI: 10.1159/000342968 & $\begin{array}{l}\text { @ 2012 S. Karger AG, Basel } \\
\text { www.karger.com/crm }\end{array}$ \\
Published online: October 26, 2012 &
\end{tabular}

Table 1. Diagnostic criteria of MetS as defined by different clinical entities

\begin{tabular}{|c|c|c|c|c|}
\hline & WHO 1998 & NCEP ATP III 2002 & IDF 2006 & $\begin{array}{l}\text { Consensus definition } \\
2009\end{array}$ \\
\hline & $\begin{array}{l}\text { Glucose intolerance, } \\
\text { impaired glucose } \\
\text { tolerance, or diabetes } \\
\text { mellitus and/or insulin } \\
\text { resistance PLUS } \geq 2 \text { of the } \\
\text { following risk factors: }\end{array}$ & $\begin{array}{l}\geq 3 \text { of the } 5 \text { following } \\
\text { metabolic risk factors: }\end{array}$ & $\begin{array}{l}\text { Central obesity (by } \\
\text { waist circumference - } \\
\text { ethnicity-specific } \\
\text { values }{ }^{\mathrm{b}} \text { or BMI } \\
>30 \mathrm{~kg} / \mathrm{m}^{2} \text { PLUS } \geq 2 \text { of } \\
\text { the following factors: }\end{array}$ & $\begin{array}{l}\geq 3 \text { of the } 5 \text { following } \\
\text { risk factors: }\end{array}$ \\
\hline BP & $\geq 160 / 90 \mathrm{~mm} \mathrm{Hg}$ & $\geq 130 / 85 \mathrm{~mm} \mathrm{Hg}$ & $\begin{array}{l}\mathrm{SBP} \geq 130 \mathrm{~mm} \mathrm{Hg} \text { or } \\
\mathrm{DBP} \geq 85 \mathrm{~mm} \mathrm{Hg} \text { or } \\
\text { current treatment } \\
\text { thereof }\end{array}$ & $\begin{array}{l}\mathrm{SBP} \geq 130 \mathrm{~mm} \mathrm{Hg} \text { and/ } \\
\text { or } \mathrm{DBP} \geq 85 \mathrm{~mm} \mathrm{Hg} \text { or } \\
\text { current treatment } \\
\text { thereof }\end{array}$ \\
\hline Obesity & $\begin{array}{l}\text { Central obesity; } \\
\text { waist:hip ratio: }>0.90 \text { in } \\
\text { men, }>0.85 \text { in women, } \\
\text { and/or BMI }>30 \mathrm{~kg} / \mathrm{m}^{2}\end{array}$ & $\begin{array}{l}\text { Abdominal obesity: } \\
>102 \mathrm{~cm} \text { (>40 inches) } \\
\text { in men; } \\
>88 \mathrm{~cm} \text { (>35 inches) } \\
\text { in women }\end{array}$ & See above & $\begin{array}{l}\text { Elevated waist } \\
\text { circumference } \\
\text { (population/country }_{\text {specific) }}{ }^{c}\end{array}$ \\
\hline $\begin{array}{l}\text { Triglyc- } \\
\text { erides }\end{array}$ & $\begin{array}{l}\geq 150 \mathrm{mg} / \mathrm{dl} \\
\text { and/or }\end{array}$ & $\geq 150 \mathrm{mg} / \mathrm{dl}$ & $\begin{array}{l}\geq 150 \mathrm{mg} / \mathrm{dl} \text { or current } \\
\text { treatment thereof }\end{array}$ & $\begin{array}{l}\geq 150 \mathrm{mg} / \mathrm{dl} \text { or current } \\
\text { treatment thereof }\end{array}$ \\
\hline HDL-C & $\begin{array}{l}<35 \mathrm{mg} / \mathrm{dl} \text { in men; } \\
<39 \mathrm{mg} / \mathrm{dl} \text { in women }\end{array}$ & $\begin{array}{l}<40 \mathrm{mg} / \mathrm{dl} \text { in men; } \\
<50 \mathrm{mg} / \mathrm{dl} \text { in women }\end{array}$ & $\begin{array}{l}<40 \mathrm{mg} / \mathrm{dl} \text { in men; } \\
<50 \mathrm{mg} / \mathrm{dl} \text { in women or } \\
\text { current treatment } \\
\text { thereof }\end{array}$ & $\begin{array}{l}<40 \mathrm{mg} / \mathrm{dl} \text { in men; } \\
<50 \mathrm{mg} / \mathrm{dl} \text { in women or } \\
\text { current treatment } \\
\text { thereof }\end{array}$ \\
\hline $\begin{array}{l}\text { Fasting } \\
\text { glucose }\end{array}$ & See above & $\geq 100 \mathrm{mg} / \mathrm{dl}^{\mathrm{a}}$ & $\begin{array}{l}\geq 100 \mathrm{mg} / \mathrm{dl} \text { or } \\
\text { previously diagnosed } \\
\text { T2DM }\end{array}$ & $\begin{array}{l}\geq 100 \mathrm{mg} / \mathrm{dl} \text { or current } \\
\text { treatment thereof }\end{array}$ \\
\hline $\begin{array}{l}\text { Micro- } \\
\text { albuminuria }\end{array}$ & $\begin{array}{l}\text { Urinary albumin excretion } \\
\geq 20 \mu \mathrm{g} / \mathrm{min} \text { or } \\
\text { albumin:creatinine ratio } \\
\geq 20 \mathrm{mg} / \mathrm{g}\end{array}$ & & & \\
\hline
\end{tabular}

${ }^{a}$ Represents American Diabetes Association updated criteria (2003); originally impaired fasting glucose was $\geq 110$ $\mathrm{mg} / \mathrm{dl}$.

${ }^{\mathrm{b}}$ IDF ethnicity-specific values (male/female) for waist circumference: Europids, Sub-Saharan Africans, Eastern Mediterranean, and Arab populations ( $\geq 37 / \geq 31.5$ inches); Japanese, Chinese, South Asians, and ethnic South and Central Americans $(\geq 35.4 / \geq 31.5$ inches).

${ }^{c}$ Consensus definition recommends 2006 IDF cut-points for non-Europeans and Europeans or a choice of AHA/ NHLBI cut-points (male/female) of $>40.2 />34.7$ inches for patients of European descent.

rovascular disease, but may not meet the laboratory definition of diabetes mellitus [14]. The original WHO criteria for CRS were a combination of two markers of insulin resistance plus two or more of the following risk factors: raised arterial pressure $(\geq 160 / 90 \mathrm{~mm} \mathrm{Hg})$, elevated triglycerides, reduced high-density lipoprotein cholesterol (HDL-C), central obesity (measured as waist:hip ratio), or microalbuminuria (which is one of the currently accepted additional criteria for CRS). There are data demonstrating that African-Americans, despite disproportionately high rates of CVD (including MI and stroke), CKD, and diabetes mellitus, have relatively lower, i.e. normal, triglyceride levels and higher HDL-C levels. Although the presence of insulin resistance, T2DM, and CVD tend to be associated with elevated triglycerides, the finding that black individuals with these conditions typically have normal triglyceride levels has led to the use of the term 'lipid paradox' or 'triglyceride paradox' [15]. Therefore, the inclusion of microalbuminuria may more appropriately identify African-Americans with CRS [16].

In 2002, the NCEP ATP III definition of MetS focused less on insulin resistance as the principal etiological factor and more on obesity and associated CV risk factors. The NCEP 


\section{CardioRenal Medicine}

ATP III definition is a positive diagnosis of MetS and requires having three or more of the following five risk factors: abdominal obesity ( $>40$ inches for men; $>35$ inches for women), elevated triglycerides ( $\geq 150 \mathrm{mg} / \mathrm{dl})$, decreased HDL-C levels $(<40 \mathrm{mg} / \mathrm{dl}$ in men; $<50 \mathrm{mg} / \mathrm{dl}$ in women), elevated $\mathrm{BP}$ ( $\geq 130 / 85 \mathrm{~mm} \mathrm{Hg}$ ), and impaired fasting glucose ( $\geq 110 \mathrm{mg} / \mathrm{dl}$ ) [17]. Three major differences between the NCEP ATP III and WHO criteria are the use of waist circumference as a measure of central obesity over waist:hip ratio, the inclusion of a lower $\mathrm{BP}$ value compatible with the 'high-normal' definition of $\mathrm{BP}$ appearing in current practice guidelines at that time [18], and the exclusion of microalbuminuria. Guidelines released in 2005 by the AHA/National Heart, Lung, and Blood Institute (NHLBI) confirmed all of the diagnostic criteria of the NCEP ATP III, with a revised criteria for impaired fasting glucose $(\geq 100 \mathrm{mg} / \mathrm{dl})$ [19].

In 2006, the IDF released consensus criteria making central obesity an integral part of the MetS definition. This report included central obesity plus any two of the following four risk factors: raised triglycerides $(\geq 150 \mathrm{mg} / \mathrm{dl})$ or treatment for raised triglycerides, decreased HDL-C levels ( $<40 \mathrm{mg} / \mathrm{dl}$ in men; $<50 \mathrm{mg} / \mathrm{dl}$ in women) or treatment to raise HDL, elevated $\mathrm{BP}$ [systolic BP (SBP) $\geq 130 \mathrm{~mm} \mathrm{Hg}$ or diastolic BP (DBP) $\geq 85 \mathrm{~mm} \mathrm{Hg}$ ] or currently on antihypertensives, or raised fasting plasma glucose $(\geq 100 \mathrm{mg} / \mathrm{dl})$ or previously diagnosed T2DM [20]. Central obesity was defined according to ethnicity-specific values or if the patient had a body mass index (BMI) $>30 \mathrm{~kg} / \mathrm{m}^{2}$. In addition to redefining clinical criteria associated with abdominal obesity, the IDF integrated the lower blood glucose value as indicative of impaired fasting glucose at $100 \mathrm{mg} / \mathrm{dl}$ from $110 \mathrm{mg} / \mathrm{dl}$.

Furthermore, a joint consensus statement from the IDF, NHLBI, AHA, World Heart Federation, International Atherosclerosis Society, and the International Association for the Study of Obesity was released in 2009 to resolve differences in the MetS definition [4]. Central to the discussion was whether central obesity should be an obligatory component of the MetS definition and whether waist circumference values should reflect differences in ethnicity, country, and sex. The consensus group concluded that waist circumference should not be an obligatory part of the MetS diagnosis. Instead, it would become one of five measures, of which three were needed for a positive diagnosis. Citing a need for continued research regarding waist circumference thresholds, the group in the interim suggested waist circumference values based on national, regional, or ethnic differences for men and women.

\section{Race/Ethnicity and Controversy in MetS/CRS Diagnosis}

Using the NCEP ATP III guidelines and 2003-2006 data from NHANES, the National Center for Health Statistics examined the prevalence of MetS in the United States among persons aged $\geq 20$ years [5]. Of the 3,423 patients surveyed, the crude, age-adjusted prevalence of MetS was 34\%. Among men, 37\% of non-Hispanic whites met the NCEP ATP III criteria of MetS compared with 33\% of Mexican-Americans and 25\% of non-Hispanic blacks. As previously mentioned, the low rates in black men are paradoxical considering the high rates of hypertension [3] and diabetes [21], two of the major diagnostic criteria of MetS/CRS, and high rates of overall CVD [10]. Considering the disproportionate rates of CVD and CKD in black men and the greater likelihood of death from CHD and stroke [10], the finding that non-Hispanic black men were half as likely as non-Hispanic white men to satisfy the MetS/ CRS criteria is a conundrum.

Mexican-American women had an estimated prevalence of $40.6 \%$, compared with $38.8 \%$ in non-Hispanic black and 31.5\% in non-Hispanic white women [5]. Similar to black men, the relatively lower rates of MetS/CRS in black women contradicts the higher rates of hypertension and obesity versus all major race/ethnic categories [3], the greater likelihood of death due 


\section{CardioRenal Medicine}

Cardiorenal Med 2012;2:256-267

\begin{tabular}{l|l} 
DOI: $10.1159 / 000342968$ & (c) 2012 S. Karger AG, Basel
\end{tabular}

Published online: October 26, 2012

www.karger.com/crm

www.karger.com/crm

to CHD versus all races [10], and higher or, at best, similar diabetes rates to Mexican-American women [5]. While non-Hispanic black and Mexican-American women were 1.5 times more likely to meet the MetS criteria than non-Hispanic white women, black women have much higher overall CVD, morbidity, and mortality than either non-Hispanic whites or Mexican-American women $[5,10]$. These overall race- and sex-based patterns of MetS were similar to those reported in 2002 by Ford et al. [22] using NHANES data from 1988-1994.

Considering the above data and other findings, despite wide clinical use of the NCEP ATP III criteria, the optimal means for identification of MetS/CRS in African-Americans remain unclear. Compared with studies using other MetS/CRS definitions, the prevalence in ATP III-based studies tends to be lower because central obesity is not an obligatory component of the definition [23-25]. Another issue is the cut-off values for triglyceride and HDL-C levels. As previously noted, African-Americans tend to have lower triglycerides and higher HDL-C levels than non-Hispanic whites [26-28]. These considerations call into question whether race-/ethnicity-based criteria should be considered for all parameters of the MetS/ CRS diagnosis, not just for waist circumference. Considering that black men and, to some extent, black women are underdiagnosed using the most popular current MetS definitions, studies are needed to explore population-based differences in biometrics in order to enhance the sensitivity of the MetS/CRS definition, and clinicians should recognize that the current MetS/CRS definition is not 'one size fits all'.

\section{Management of High BP and Hypertension in MetS}

CVD risk increases in a linear fashion before conventional hypertensive BP levels are reached. Current practice guidelines arise out of the detailed assessment of available clinical evidence and define hypertension as an SBP $\geq 140 \mathrm{~mm} \mathrm{Hg}$ or DBP $\geq 90 \mathrm{~mm} \mathrm{Hg}[29,30]$, which is well above optimal or normal levels. For most patients, a treatment goal BP of $<140 / 90 \mathrm{~mm} \mathrm{Hg}$ is recommended, while for patients with renal disease or diabetes mellitus, a more stringent goal of $<130 / 80 \mathrm{~mm} \mathrm{Hg}$ has been recommended [29, 30]. It should be noted that prospective clinical trial data do not currently support starting antihypertensive drug therapy in patients with diabetes and high-normal BP, and therefore it may be beneficial to initiate such therapy only if subclinical organ damage is present [8]. In fact, the recent 2012 joint European Society of Hypertension/European Society of Cardiology (ESH/ESC) guidelines on CVD prevention recommend that the BP target in patients with diabetes should be $<140 / 80 \mathrm{~mm} \mathrm{Hg}$.

However, there are CV risks associated with BP levels below this somewhat arbitrary hypertension threshold, described in different guidelines as prehypertension (SBP of 120$139 \mathrm{~mm} \mathrm{Hg}$ or DBP of 80-89 mm Hg) [29] or high-normal BP (SBP of 130-139 mm Hg or DBP of $85-89 \mathrm{~mm} \mathrm{Hg}$ ) [30]. Beginning with a BP of $115 / 75 \mathrm{~mm} \mathrm{Hg}$, every $20-\mathrm{mm} \mathrm{Hg}$ increase in SBP and every 10-mm Hg increase in DBP doubles the risk of death due to stroke, angina, MI, and heart failure [31]. Therefore, the recognition of increased CVD risk before the arbitrary BP level defined as hypertension is important in patients with MetS/CRS, who are likely to have elevated BP. In patients with MetS aged 39-64 years, rates of high BP (defined as $\mathrm{SBP} \geq 130 \mathrm{~mm} \mathrm{Hg}$ or DBP $\geq 85 \mathrm{~mm} \mathrm{Hg}$ ) range from 39 to $50 \%$ in men and from 29 to $40 \%$ in women [32], and, not unexpectedly, rates of high BP are $70-80 \%$ in men and women aged $\geq 65$ years [32]. Consequently, it may be beneficial to initiate BP-lowering therapy before apparent organ damage, or while it is still reversible [8].

The Seventh Report of the Joint National Committee on Prevention, Detection, Evaluation, and Treatment of High Blood Pressure (JNC 7) and the 2007 ESH/ESC hypertension treatment guidelines advised managing patients with MetS who have prehypertension or 


\section{CardioRenal Medicine}

high-normal BP by encouraging lifestyle modifications [29, 30]. Beyond lifestyle modifications, the JNC 7 treatment guidelines do not specifically address pharmacological management of BP in the patient with MetS until BP exceeds the threshold of 140/90 mm Hg, unless comorbid T2DM or renal disease are present. In patients with MetS, the $2007 \mathrm{ESH} / \mathrm{ESC}$ guidelines advise clinicians to consider pharmacotherapy along with lifestyle modifications in high-normal BP; however, they also note these recommendations are not firm because of the lack of interventional trials in this population [30]. As to choosing the most beneficial antihypertensive agent for MetS/CRS, the $2007 \mathrm{ESH} / \mathrm{ESC}$ guidelines recommend an angiotensin-converting enzyme inhibitor (ACEI) or an angiotensin receptor blocker (ARB) not only because they may help delay the progression to hypertension and T2DM, but also due to their superior protective effect against initiation or progression of nephropathy/renal damage $[8,30,33,34]$. However, the upcoming JNC 8 hypertension guidelines may re-evaluate the current $\mathrm{BP}$ goal of $<130 / 80 \mathrm{~mm} \mathrm{Hg}$ for patients with hypertension, $\mathrm{T} 2 \mathrm{DM}$, and CKD, considering limited clinical evidence from major outcomes trials [35, 36].

Considering the high rates of obesity, dysglycemia, and CKD, achieving BP control can be difficult in patients with MetS/CRS, who are also more likely to have treatment-resistant hypertension. According to NHANES data from 2007-2008, only $50 \%$ of all patients with diagnosed hypertension achieve BP control [37]. Clinicians need to be aware that, for most patients, $\mathrm{BP}$ control rates range from 27 to $37 \%$ with antihypertensive monotherapy, versus as high as from 53 to $75 \%$ with combination therapy [38-40].

When monotherapy fails to achieve the BP goal in patients with hypertension and MetS, the $2007 \mathrm{ESH} / \mathrm{ESC}$ guidelines recommend adding a calcium channel blocker (CCB) to an $\mathrm{ACEI}$ or ARB, or using a thiazide diuretic as second- or third-line therapy [30]. Data have shown that three agents may be required to control BP in $15-20 \%$ of patients with hypertension, and using a renin-angiotensin system (RAS) blocker, CCB, and diuretic appears to be a rational combination [41]. Combining agents from different antihypertensive drug classes results in BP lowering approximately five times greater versus doubling the monotherapy dose [41]. Furthermore, fixed-dose combinations (FDCs) may increase compliance by simplifying treatment regimens. Compared with a $\beta$-blocker/thiazide diuretic combination, a $\mathrm{CCB} / \mathrm{ACEI}$ combination prevented more total $\mathrm{CV}$ events and procedures $(1,362$ vs. 1,602 ; $\mathrm{p}<0.0001$ ) and new-onset diabetes cases (567 vs. 799; $\mathrm{p}<0.0001$ ) in the Anglo-Scandinavian Cardiac Outcomes Trial-Blood Pressure Lowering Arm (ASCOT-BPLA) [42]. However, these were secondary endpoints, and no statistically significant difference was detected in the primary endpoint, the composite of nonfatal MI (including silent MI) and fatal CHD (429 vs. 474 cases; $p=0.1052)$. In recognition of the difficulty translating European data to a more heterogeneous US population, it is noteworthy that only approximately $5 \%$ of the study population in ASCOT-BPLA was black [43].

The case for utilization of a RAS blocker plus CCB combination therapy was supported in the Avoiding Cardiovascular Events Through Combination Therapy in Patients Living with Systolic Hypertension (ACCOMPLISH) trial, wherein a benazepril (BEN) plus amlodipine (AML) treatment regimen prevented more primary outcome events (death from $\mathrm{CV}$ causes and CV events) than BEN plus hydrochlorothiazide (HCTZ; p < 0.001) [40]. A recent subgroup analysis of ACCOMPLISH evaluating renal outcomes in the black cohort of the study population demonstrated that there was no difference in mean estimated GFR loss in the black cohort between the treatment regimens; however, BEN/AML combination therapy was more effective than BEN/HCTZ in stabilizing estimated GFR/reducing kidney disease progression in non-blacks [44]. There was no difference between the black and non-black cohorts for the composite kidney disease endpoint (i.e. doubling in serum creatinine, endstage renal disease, or death), although black patients were significantly more likely to have a $>50 \%$ increase in serum creatinine. 


\section{CardioRenal Medicine}

In The Antihypertensive and Lipid-Lowering Treatment to Prevent Heart Attack Trial (ALLHAT) [45], there was no significant difference in the primary endpoint of fatal CHD or nonfatal MI between chlorthalidone and lisinopril or AML [46]. Furthermore, in a subgroup analysis of patients with MetS or diabetes, there were no significant differences in the relative risks of CHD, all-cause mortality, stroke, or end-stage renal disease in patients treated with chlorthalidone compared with either lisinopril or AML [47]. However, the risk of heart failure and combined CVD was significantly greater in patients with MetS treated with lisinopril versus chlorthalidone [47]. Recent data from the ALLHAT Diabetes Extension Study showed that in those study patients who developed incident diabetes mellitus versus nondiabetic patients, the lowest hazard ratios for CVD mortality, total mortality, non-CV mortality, CHD, and stroke were observed in the chlorthalidone group [48]. Incident diabetes mellitus did not have a significant adverse effect on the risk for any outcome in the chlorthalidone group. For a patient who is naïve to antihypertensive therapy, treatment with a thiazidetype diuretic is considered a good first choice on the basis of these endpoints alone. However, as previously noted, most patients require combination therapy, and the ALLHAT study design did not assess the benefits of structured combination therapy, such as a RAS blocker paired with a thiazide-type diuretic or CCB, as commonly prescribed today. Of the total ALLHAT study population, approximately $32 \%$ of randomized patients were black and $16 \%$ were Hispanic [46].

In the Losartan Intervention for Endpoint Reduction (LIFE) study [39], 508 patients in the losartan group and 588 patients in the atenolol group reached the primary composite endpoint (CV death, MI, and stroke) at study end. This was a statistically significant finding before and after adjustment for the Framingham Risk Score $(\mathrm{p}=0.009$ and $\mathrm{p}=0.021$, respectively) [39]. In addition, the losartan group experienced significantly fewer incidences of stroke than the atenolol group (232 vs. 309; $p=0.001$ and $p=0.0006$ before and after adjustment, respectively) [39]. A significantly lower incidence of new-onset diabetes was seen in losartan patients not having diabetes at baseline ( 6 vs. $8 \%$; $p=0.001$ for both adjusted and unadjusted analyses) [39]. Unfortunately, the black and Hispanic cohorts were too small (6 and $1 \%$, respectively) to confirm any CVD or stroke benefit with an ARB-based regimen [39, 49]. Importantly, a recent substudy of LIFE evaluating racial differences in sudden cardiac death showed that the 5-year sudden cardiac death incidence was significantly higher in black versus non-black patients ( 3.9 vs. $1.9 \%$; $p=0.007$ ). Even after multivariate Cox analyses, black race was associated with a $98 \%$ increased risk of sudden cardiac death $(p=0.020)$ [50].

In the BP arm of the Action to Control Cardiovascular Risk in Diabetes (ACCORD BP) trial [35], patients were randomized to intensive or standard BP control [51]. For the primary outcome (composite of nonfatal MI, nonfatal stroke, and CV death), there were 208 events in the intensive versus 237 in the standard therapy group $(\mathrm{p}=0.20)$ [35]. For the secondary endpoints of any stroke and nonfatal stroke, there were statistically significantly fewer events for both in the intensive versus standard control groups ( $\mathrm{p}=0.01$ and $\mathrm{p}=0.03$, respectively) [35]. This finding could indicate some benefit attributable to the lower mean SBP achieved in the intensive versus standard therapy group (119 vs. $133 \mathrm{~mm} \mathrm{Hg}$, respectively). Therefore, despite the nonsignificant findings of the primary endpoint, achieving a lower BP in patients with T2DM at higher risk for stroke may be advisable. It remains unclear whether this finding will prompt a revision of hypertension or MetS/CRS guidelines, especially considering the statistically insignificant higher incidence of deaths from any cause observed in the intensive treatment group (150 vs. 144; $\mathrm{p}=0.55$ ) [35]. The American Diabetes Association 2012 practice recommendation notes a $\mathrm{BP}$ goal of $<130 / 80 \mathrm{~mm} \mathrm{Hg}$ for persons with diabetes, which may be lower or higher depending on individual patient characteristics [52]. Although no specific race/ethnicity data were reported, approximately $24 \%$ of the study population in ACCORD was black and 7\% Hispanic [35]. 


\section{CardioRenal Medicine}

\begin{tabular}{|c|c|}
\hline \multicolumn{2}{|l|}{ Cardiorenal Med 2012;2:256-267 } \\
\hline $\begin{array}{l}\text { DOI: } 10.1159 / 000342968 \\
\text { Published online: October 26, } 2012\end{array}$ & $\begin{array}{l}\text { (c) } 2012 \text { S. Karger AG, Basel } \\
\text { www.karger.com/crm }\end{array}$ \\
\hline
\end{tabular}

\section{Recent OImesartan Medoxomil Efficacy Studies Supporting a RAS Inhibitor-Based Treatment Strategy}

Although CVD morbidity/mortality studies are essential to determine guidelines and evidence-based antihypertensive therapy, recent olmesartan medoxomil (OM) efficacy studies support the utilization of RAS blockers, alone or in combination, to achieve the BP goal in patients at increased risk. An ambulatory $\mathrm{BP}(\mathrm{ABP})$ monitoring study assessed the efficacy of an AML/OM \pm HCTZ combination therapy in patients with hypertension and T2DM [53]. At baseline, the mean 24-hour ABP was 144.4/81.6 mm Hg. After 12 weeks of active treatment, the mean $\mathrm{ABP}$ was significantly reduced by $-19.9 /-11.2 \mathrm{~mm} \mathrm{Hg}(\mathrm{p}<0.0001$ vs. baseline), with $72 \%$ of patients titrated to triple therapy (AML/OM + HCTZ) [53]. Approximately $70 \%$ of the patients achieved a 24 -hour ABP target of $<130 / 80 \mathrm{~mm} \mathrm{Hg}$. The seated cuff (Se) BP goal of $<130 / 80 \mathrm{~mm} \mathrm{Hg}$ for patients with T2DM was achieved by $62 \%$ of the patients after 18 weeks of treatment [53]. Blacks and Hispanics comprised 17 and 26\% of the study population, respectively [53], and $81 \%$ of the patients had MetS [54].

Another study investigated BP goal achievement in patients with hypertension $(46.2 \%$ had MetS) inadequately controlled on antihypertensive monotherapy who were switched to an AML/OM $\pm \mathrm{HCTZ}$ combination therapy titration regimen [55]. After 12 weeks of treatment, $75.8 \%$ of the patients achieved the SeSBP goal of $<140 \mathrm{~mm} \mathrm{Hg}$ (or $<130 \mathrm{~mm} \mathrm{Hg}$ for patients with diabetes) [55]. The BP goal of $<140 / 90 \mathrm{~mm} \mathrm{Hg}(<130 / 80 \mathrm{~mm} \mathrm{Hg}$ if diabetes) was achieved by 71.3 and $84.8 \%$ of the patients by weeks 12 and 20 , respectively, and $90.3 \%$ achieved the cumulative BP threshold of $<140 / 90 \mathrm{~mm} \mathrm{Hg}$ by week 20 [55]. The study population consisted of $23.4 \%$ black patients and $10.5 \%$ Hispanic patients [55]. Preliminary data from a 2010 abstract demonstrated that, at any time point by week 20, a cumulative SeBP goal of $<140 / 90 \mathrm{~mm} \mathrm{Hg}$ was achieved by 86.6 and $88.0 \%$ of black and Hispanic patients, respectively [56]. Other RAS-blocking agents in combination with AML/HCTZ are also available and have demonstrated efficacy in achieving BP goals (see online suppl. table; www. karger.com/doi/10.1159/000342968).

\section{Potential Benefits of FDC Therapy}

Patients with MetS/CRS are often being treated concomitantly for other metabolic abnormalities such as dyslipidemia, glucose intolerance, or insulin resistance. Managing hypertension in these patients can increase pill burden as multiple medications may be needed [38]. When appropriate and possible, clinicians should strive to simplify treatment regimens through the use of FDC (single-pill) therapy. Once-daily FDC formulations decrease the daily pill burden and may improve adherence. In a randomized trial in Canada, a simplified treatment regimen utilizing FDC therapy and a clearly defined algorithm for dose escalation was compared with conventional guideline-based care for achieving the BP goal. At 6 months, $64.7 \%$ of the patients in the FDC therapy simplified treatment arm achieved the BP goal versus $52.7 \%$ in the conventional treatment group $(\mathrm{p}=0.026)$ [57].

In a meta-analysis of nine studies reporting adherence data, FDC therapy reduced medication nonadherence by $26 \%(\mathrm{p}<0.0001)$ versus non-FDC regimens [58]. A subgroup analysis of the four antihypertensive therapy studies showed that FDC therapy decreased medication nonadherence by $24 \%(\mathrm{p}<0.0001)$ [58]. FDCs combining the benefits of RAS blockers with HCTZ are available, as are combinations with CCBs, and should be considered when appropriate for the management of hypertension.

FDCs may not be of benefit to all patients. FDC antihypertensives can be more expensive than the generic component medications. Not excluding the uninsured, the coverage pro- 


\section{CardioRenal Medicine}

vided by insurance plans, Medicare, and Medicaid may make FDC therapy too expensive for lower-income patients or for patients for whom cost concerns may outweigh the benefits of decreased pill burden or improved adherence. Although generic substitution programs offered by major pharmacy chains provide lower-cost access to antihypertensive agents, unfortunately, the generic formularies usually offer a limited range of agents, including fewer FDCs [43]. Alternatively, pharmaceutical industry patient-in-need programs can provide some branded antihypertensive agents at zero cost to the patient. Another important consideration with FDCs is that they may limit the flexibility to adjust the dosage of one component depending on a variety of clinical scenarios. Finally, it may not always be apparent which component of an FDC is responsible for an adverse event or intolerance.

\section{Conclusions}

A need exists to increase scientific knowledge with regards to MetS/CRS and diagnostic criteria. CKD has increased to epidemic proportions across the industrialized nations and is even more prevalent in socioeconomically deprived individuals and minorities. Moreover, patients with CRS are identified to be at greater risk for developing CKD. Consequently, it is imperative that patients with MetS, especially those populations at increased risk for CKD, be evaluated for microalbuminuria and/or reduced renal function in order to reduce the number of patients developing CKD and end-stage renal disease. Studies focusing specifically on racial/ethnic minorities will help to broaden the available data for consideration when constructing future practice guidelines and ensure that diagnostic criteria do not leave certain ethnic or racial populations underdiagnosed. MetS/CRS is quickly becoming a global health epidemic because of its increased prevalence and association with CVD, diabetes mellitus, and CKD, and associated health care costs are expected to rise dramatically in developed countries. Considering the association of hypertension with increased CV mortality, effective lifestyle modifications and antihypertensive therapy are important. Given that patients with MetS/CRS have multiple comorbidities and, therefore, receive numerous riskreducing medications, appropriate antihypertensive fixed-dose double or triple combination therapy should be considered whenever appropriate. By recognizing and effectively treating risk factors associated with MetS/CRS, clinicians can potentially improve patient outcomes and help to reduce the burden on health care resources imposed by MetS/CRS and its complications.

\section{Acknowledgements}

I would like to thank Robert Schupp, PharmD, and Alan J. Klopp, PhD, of inScience Communications, Springer Healthcare, for providing medical writing support funded by Daiichi Sankyo, Inc.

\section{Disclosure Statement}

Dr. Ferdinand has received research grants from Daiichi Sankyo, Inc. and Novartis. He has served as a consultant for AstraZeneca, Forest Laboratories, Merck, Novartis, Sanofi, and Takeda Pharmaceuticals. 


\section{CardioRenal Medicine}

\begin{tabular}{l|l}
\hline Cardiorenal Med 2012;2:256-267 \\
\hline DOI: 10.1159/000342968 \\
Published online: October 26, 2012 & $\begin{array}{l}\text { @ 2012 S. Karger AG, Basel } \\
\text { www.karger.com/crm }\end{array}$ \\
\hline
\end{tabular}

Ferdinand et al.: Emerging Concepts in Hypertension and Metabolic Syndrome

\section{References}

1 Alberti KG, Zimmet P, Shaw J: The metabolic syndrome - a new worldwide definition. Lancet 2005;366:1059-1062.

-2 Cornier MA, Dabelea D, Hernandez TL, Lindstrom RC, Steig AJ, Stob NR, Van Pelt RE, Wang H, Eckel RH: The metabolic syndrome. Endocr Rev 2008;29:777-822.

-3 Roger VL, Go AS, Lloyd-Jones DM, Benjamin EJ, Berry JD, Borden WB, Bravata DM, Dai S, Ford ES, Fox CS, Fullerton HJ, Gillespie C, Hailpern SM, Heit JA, Howard VJ, Kissela BM, Kittner SJ, Lackland DT, Lichtman JH, Lisabeth LD, Makuc DM, Marcus GM, Marelli A, Matchar DB, Moy CS, Mozaffarian D, Mussolino ME, Nichol G, Paynter NP, Soliman EZ, Sorlie PD, Sotoodehnia N, Turan TN, Virani SS, Wong ND, Woo D, Turner MB: Heart disease and stroke statistics - 2012 update: a report from the American Heart Association. Circulation 2012;125:e2-e220.

-4 Alberti KG, Eckel RH, Grundy SM, Zimmet PZ, Cleeman JI, Donato KA, Fruchart JC, James WP, Loria CM, Smith SC Jr: Harmonizing the metabolic syndrome: a joint interim statement of the International Diabetes Federation Task Force on Epidemiology and Prevention; National Heart, Lung, and Blood Institute; American Heart Association; World Heart Federation; International Atherosclerosis Society; and International Association for the Study of Obesity. Circulation 2009;120:1640-1645.

-5 Ervin RB: Prevalence of metabolic syndrome among adults 20 years of age and over, by sex, age, race and ethnicity, and body mass index: United States, 2003-2006. Natl Health Stat Report 2009;13:1-7.

6 Mottillo S, Filion KB, Genest J, Joseph L, Pilote L, Poirier P, Rinfret S, Schiffrin EL, Eisenberg MJ: The metabolic syndrome and cardiovascular risk: a systematic review and meta-analysis. J Am Coll Cardiol 2010;56:1113-1132.

7 Sowers JR, Whaley-Connell A, Hayden MR: The role of overweight and obesity in the cardiorenal syndrome. Cardiorenal Med 2011;1:5-12.

-8 Perk J, De Backer G, Gohlke H, Graham I, Reiner Z, Verschuren M, Albus C, Benlian P, Boysen G, Cifkova R, Deaton C, Ebrahim S, Fisher M, Germano G, Hobbs R, Hoes A, Karadeniz S, Mezzani A, Prescott E, Ryden L, Scherer M, Syvanne M, Scholte op Reimer W, Vrints CJ, Wood D, Zamorano JL, Zannad F: European Guidelines on cardiovascular disease prevention in clinical practice (version 2012). The Fifth Joint Task Force of the European Society of Cardiology and Other Societies on Cardiovascular Disease Prevention in Clinical Practice (constituted by representatives of nine societies and by invited experts). Developed with the special contribution of the Euopean Association for Cardiovascular Prevention and Rehabilitation (EACPR). Eur Heart J 2012;33:1635-1701.

-9 Ford ES, Schulze MB, Pischon T, Bergmann MM, Joost HG, Boeing H: Metabolic syndrome and risk of incident diabetes: findings from the European Prospective Investigation into Cancer and Nutrition-Potsdam Study. Cardiovasc Diabetol 2008; 7:35.

10 Centers for Disease Control and Prevention: MMWR - CDC Health Disparities and Inequalities Report-United States, 2011. http://www.cdc.gov/mmwr/pdf/other/su6001.pdf (accessed February 14, 2012).

11 Hertz RP, Unger AN, Cornell JA, Saunders E: Racial disparities in hypertension prevalence, awareness, and management. Arch Intern Med 2005;165:2098-2104.

12 Centers for Disease Control and Prevention (CDC): Prevalence of chronic kidney disease and associated risk factors - United States, 1999-2004. MMWR Morb Mortal Wkly Rep 2007;56:161-165.

13 Meigs JB: The metabolic syndrome (insulin resistance syndrome or syndrome X). http://www.uptodate.com/online/ content/topic.do?topicKey=diabetes/21989\&view=print (accessed May 12, 2012).

- 14 Alberti KG, Zimmet PZ: Definition, diagnosis and classification of diabetes mellitus and its complications. Part 1: diagnosis and classification of diabetes mellitus provisional report of a WHO consultation. Diabet Med 1998;15:539553.

15 Yu SS, Castillo DC, Courville AB, Sumner AE: The triglyceride paradox in people of African descent. Metab Syndr Relat Disord 2012;10:77-82.

16 Okpechi IG, Pascoe MD, Swanepoel CR, Rayner BL: Microalbuminuria and the metabolic syndrome in non-diabetic black Africans. Diab Vasc Dis Res 2007;4:365-367.

- 17 National Cholesterol Education Program (NCEP) Expert Panel on Detection, Evaluation, and Treatment of High Blood Cholesterol in Adults (Adult Treatment Panel III): Third Report of the National Cholesterol Education Program (NCEP) Expert Panel on Detection, Evaluation, and Treatment of High Blood Cholesterol in Adults (Adult Treatment Panel III) final report. Circulation 2002;106:3143-3421.

18 Joint National Committee on Prevention, Detection, Evaluation, and Treatment of High Blood Pressure: The sixth report of the Joint National Committee on Prevention, Detection, Evaluation, and Treatment of High Blood Pressure. Arch Intern Med 1997;157:2413-2446.

19 Grundy SM, Cleeman JI, Daniels SR, Donato KA, Eckel RH, Franklin BA, Gordon DJ, Krauss RM, Savage PJ, Smith SC Jr, Spertus JA, Costa F: Diagnosis and management of the metabolic syndrome: an American Heart Association/ National Heart, Lung, and Blood Institute Scientific Statement. Circulation 2005;112:2735-2752.

20 International Diabetes Federation: The IDF consensus worldwide definition of the metabolic syndrome. http://www. idf.org/webdata/docs/IDF_Meta_def_final.pdf (accessed April 15, 2012).

21 Centers for Disease Control and Prevention: National Diabetes Fact Sheet, 2011. http://www.cdc.gov/diabetes/pubs/ pdf/ndfs_2011.pdf (accessed February 14, 2012).

-22 Ford ES, Giles WH, Dietz WH: Prevalence of the metabolic syndrome among US adults: findings from the third National Health and Nutrition Examination Survey. JAMA 2002;287:356-359. 


\section{CardioRenal Medicine}

\begin{tabular}{l|l}
\hline Cardiorenal Med 2012;2:256-267 \\
\hline DOI: 10.1159/000342968 \\
Published online: October 26, 2012 & $\begin{array}{l}\text { @ 2012 S. Karger AG, Basel } \\
\text { www.karger.com/crm }\end{array}$ \\
\hline
\end{tabular}

Ferdinand et al.: Emerging Concepts in Hypertension and Metabolic Syndrome

23 Ford ES, Giles WH: A comparison of the prevalence of the metabolic syndrome using two proposed definitions. Diabetes Care 2003;26:575-581.

-24 Mancia G, Bombelli M, Facchetti R, Casati A, Ronchi I, Quarti-Trevano F, Arenare F, Grassi G, Sega R: Impact of different definitions of the metabolic syndrome on the prevalence of organ damage, cardiometabolic risk and cardiovascular events. J Hypertens 2010;28:999-1006.

25 Waterhouse DF, McLaughlin AM, Sheehan F, O'Shea D: An examination of the prevalence of IDF- and ATPIII-defined metabolic syndrome in an Irish screening population. Ir J Med Sci 2009;178:161-166.

26 Cowie CC, Howard BV, Harris MI: Serum lipoproteins in African Americans and whites with non-insulin-dependent diabetes in the US population. Circulation 1994;90:1185-1193.

27 Imoisili OE, Sumner AE: Preventing diabetes and atherosclerosis in Sub-Saharan Africa: should the metabolic syndrome have a role? Curr Cardiovasc Risk Rep 2009;3:161-167.

28 Meis SB, Schuster D, Gaillard T, Osei K: Metabolic syndrome in nondiabetic, obese, first-degree relatives of African American patients with type 2 diabetes: African American triglycerides-HDL-C and insulin resistance paradox. Ethn Dis 2006; 16:830-836.

-29 Chobanian AV, Bakris GL, Black HR, Cushman WC, Green LA, Izzo JL Jr, Jones DW, Materson BJ, Oparil S, Wright JT Jr, Roccella EJ: The Seventh Report of the Joint National Committee on Prevention, Detection, Evaluation, and Treatment of High Blood Pressure: the JNC 7 report. JAMA 2003;289:2560-2572.

-30 Mancia G, De Backer G, Dominiczak A, Cifkova R, Fagard R, Germano G, Grassi G, Heagerty AM, Kjeldsen SE, Laurent S, Narkiewicz K, Ruilope L, Rynkiewicz A, Schmieder RE, Boudier HA, Zanchetti A, Vahanian A, Camm J, De Caterina R, Dean V, Dickstein K, Filippatos G, Funck-Brentano C, Hellemans I, Kristensen SD, McGregor K, Sechtem U, Silber S, Tendera M, Widimsky P, Zamorano JL, Erdine S, Kiowski W, Agabiti-Rosei E, Ambrosioni E, Lindholm LH, Viigimaa M, Adamopoulos S, Bertomeu V, Clement D, Farsang C, Gaita D, Lip G, Mallion JM, Manolis AJ, Nilsson PM, O’Brien E, Ponikowski P, Redon J, Ruschitzka F, Tamargo J, van Zwieten P, Waeber B, Williams B: 2007 Guidelines for the Management of Arterial Hypertension: The Task Force for the Management of Arterial Hypertension of the European Society of Hypertension (ESH) and of the European Society of Cardiology (ESC). J Hypertens 2007;25:1105-1187.

- 31 Lewington S, Clarke R, Qizilbash N, Peto R, Collins R: Age-specific relevance of usual blood pressure to vascular mortality: a meta-analysis of individual data for one million adults in 61 prospective studies. Lancet 2002;360:19031913.

- 32 Park YW, Zhu S, Palaniappan L, Heshka S, Carnethon MR, Heymsfield SB: The metabolic syndrome: prevalence and associated risk factor findings in the US population from the Third National Health and Nutrition Examination Survey, 1988-1994. Arch Intern Med 2003;163:427-436.

- 33 Abuissa H, Jones PG, Marso SP, O’Keefe JH Jr: Angiotensin-converting enzyme inhibitors or angiotensin receptor blockers for prevention of type 2 diabetes: a meta-analysis of randomized clinical trials. J Am Coll Cardiol 2005;46: $821-826$.

-34 Julius S, Nesbitt SD, Egan BM, Weber MA, Michelson EL, Kaciroti N, Black HR, Grimm RH Jr, Messerli FH, Oparil S, Schork MA: Feasibility of treating prehypertension with an angiotensin-receptor blocker. N Engl J Med 2006;354: 1685-1697.

- 35 Cushman WC, Evans GW, Byington RP, Goff DC Jr, Grimm RH Jr, Cutler JA, Simons-Morton DG, Basile JN, Corson MA, Probstfield JL, Katz L, Peterson KA, Friedewald WT, Buse JB, Bigger JT, Gerstein HC, Ismail-Beigi F: Effects of intensive blood-pressure control in type 2 diabetes mellitus. N Engl J Med 2010;362:1575-1585.

-36 Appel LJ, Wright JT Jr, Greene T, Agodoa LY, Astor BC, Bakris GL, Cleveland WH, Charleston J, Contreras G, Faulkner ML, Gabbai FB, Gassman JJ, Hebert LA, Jamerson KA, Kopple JD, Kusek JW, Lash JP, Lea JP, Lewis JB, Lipkowitz MS, Massry SG, Miller ER, Norris K, Phillips RA, Pogue VA, Randall OS, Rostand SG, Smogorzewski MJ, Toto RD, Wang $\mathrm{X}$ : Intensive blood-pressure control in hypertensive chronic kidney disease. N Engl J Med 2010;363:918-929.

37 Egan BM, Zhao Y, Axon RN: US trends in prevalence, awareness, treatment, and control of hypertension, 1988-2008. JAMA 2010;303:2043-2050.

- 38 Cushman WC, Ford CE, Cutler JA, Margolis KL, Davis BR, Grimm RH, Black HR, Hamilton BP, Holland J, Nwachuku C, Papademetriou V, Probstfield J, Wright JT Jr, Alderman MH, Weiss RJ, Piller L, Bettencourt J, Walsh SM: Success and predictors of blood pressure control in diverse North American settings: the antihypertensive and lipidlowering treatment to prevent heart attack trial (ALLHAT). J Clin Hypertens (Greenwich) 2002;4:393-404.

-39 Dahlof B, Devereux RB, Kjeldsen SE, Julius S, Beevers G, de Faire U, Fyhrquist F, Ibsen H, Kristiansson K, Lederballe-Pedersen O, Lindholm LH, Nieminen MS, Omvik P, Oparil S, Wedel H: Cardiovascular morbidity and mortality in the Losartan Intervention For Endpoint reduction in hypertension study (LIFE): a randomised trial against atenolol. Lancet 2002;359:995-1003.

- 40 Jamerson K, Weber MA, Bakris GL, Dahlof B, Pitt B, Shi V, Hester A, Gupte J, Gatlin M, Velazquez EJ: Benazepril plus amlodipine or hydrochlorothiazide for hypertension in high-risk patients. N Engl J Med 2008;359:2417-2428.

41 Wald DS, Law M, Morris JK, Bestwick JP, Wald NJ: Combination therapy versus monotherapy in reducing blood pressure: meta-analysis on 11,000 participants from 42 trials. Am J Med 2009;122:290-300.

-42 Dahlof B, Sever PS, Poulter NR, Wedel H, Beevers DG, Caulfield M, Collins R, Kjeldsen SE, Kristinsson A, McInnes GT, Mehlsen J, Nieminen M, O’Brien E, Ostergren J: Prevention of cardiovascular events with an antihypertensive regimen of amlodipine adding perindopril as required versus atenolol adding bendroflumethiazide as required, in the Anglo-Scandinavian Cardiac Outcomes Trial-Blood Pressure Lowering Arm (ASCOT-BPLA): a multicentre randomised controlled trial. Lancet 2005;366:895-906. 


\section{CardioRenal Medicine}

\begin{tabular}{l|l}
\hline \multicolumn{2}{l}{ Cardiorenal Med 2012;2:256-267 } \\
\hline DOI: 10.1159/000342968 & $\begin{array}{l}\text { @ 2012 S. Karger AG, Basel } \\
\text { www.karger.com/crm }\end{array}$ \\
\hline Published online: October 26, 2012
\end{tabular}

Ferdinand et al.: Emerging Concepts in Hypertension and Metabolic Syndrome

-43 Flack JM, Sica DA, Bakris G, Brown AL, Ferdinand KC, Grimm RH Jr, Hall WD, Jones WE, Kountz DS, Lea JP, Nasser S, Nesbitt SD, Saunders E, Scisney-Matlock M, Jamerson KA: Management of high blood pressure in blacks: an update of the International Society on Hypertension in Blacks consensus statement. Hypertension 2010;56:780-800.

-44 Weir MR, Bakris GL, Weber MA, Dahlof B, Devereux RB, Kjeldsen SE, Pitt B, Wright JT, Kelly RY, Hua TA, Hester RA, Velazquez E, Jamerson KA: Renal outcomes in hypertensive Black patients at high cardiovascular risk. Kidney Int 2012;81:568-576.

-45 ALLHAT Collaborative Research Group: Major cardiovascular events in hypertensive patients randomized to doxazosin vs chlorthalidone: the antihypertensive and lipid-lowering treatment to prevent heart attack trial (ALLHAT). JAMA 2000;283:1967-1975.

-46 ALLHAT Officers and Coordinators for the ALLHAT Collaborative Research Group: Major outcomes in high-risk hypertensive patients randomized to angiotensin-converting enzyme inhibitor or calcium channel blocker vs diuretic: The Antihypertensive and Lipid-Lowering Treatment to Prevent Heart Attack Trial (ALLHAT). JAMA 2002;288: 2981-2997.

-47 Black HR, Davis B, Barzilay J, Nwachuku C, Baimbridge C, Marginean H, Wright JT Jr, Basile J, Wong ND, Whelton P, Dart RA, Thadani U: Metabolic and clinical outcomes in nondiabetic individuals with the metabolic syndrome assigned to chlorthalidone, amlodipine, or lisinopril as initial treatment for hypertension: a report from the Antihypertensive and Lipid-Lowering Treatment to Prevent Heart Attack Trial (ALLHAT). Diabetes Care 2008;31:353-360.

48 Barzilay JI, Davis BR, Pressel SL, Cutler JA, Einhorn PT, Black HR, Cushman WC, Ford CE, Margolis KL, Moloo J, Oparil S, Piller LB, Simmons DL, Sweeney ME, Whelton PK, Wong ND, Wright JT Jr: Long-term effects of incident diabetes mellitus on cardiovascular outcomes in people treated for hypertension: the ALLHAT Diabetes Extension Study. Circ Cardiovasc Qual Outcomes 2012;5:153-162.

49 COZAAR (losartan potassium tablets). Whitehouse Station, NJ: Merck Sharp \& Dohme; 2011.

50 Okin PM, Kjeldsen SE, Julius S, Dahlof B, Devereux RB: Racial differences in sudden cardiac death among hypertensive patients during antihypertensive therapy: the LIFE study. Heart Rhythm 2012;9:531-537.

-51 Cushman WC, Grimm RH Jr, Cutler JA, Evans GW, Capes S, Corson MA, Sadler LS, Alderman MH, Peterson K, Bertoni A, Basile JN: Rationale and design for the blood pressure intervention of the Action to Control Cardiovascular Risk in Diabetes (ACCORD) trial. Am J Cardiol 2007;99:44i-55i.

52 American Diabetes Association: Standards of medical care in diabetes - 2012. Diabetes Care 2012;35(suppl 1):S11-S63.

-53 Ram CV, Sachson R, Littlejohn T, Qian C, Shojaee A, Stoakes KA, Neutel JM: Management of hypertension in patients with diabetes using an amlodipine-, olmesartan medoxomil-, and hydrochlorothiazide-based titration regimen. Am J Cardiol 2011;107:1346-1352.

54 Ram VS, Sachson RA, Qian C, Patel M, Stoakes KA: Effects of an amlodipine- and olmesartan medoxomil-based titration regiment in patients with hypertension, type 2 diabetes and metabolic syndrome. J Clin Hypertens 2010; 12:A96.

55 Weir MR, Hsueh WA, Nesbitt SD, Littlejohn TJ, 3rd, Graff A, Shojaee A, Waverczak WF, Qian C, Jones CJ, Neutel JM: A titrate-to-goal study of switching patients uncontrolled on antihypertensive monotherapy to fixed-dose combinations of amlodipine and olmesartan medoxomil +/- hydrochlorothiazide. J Clin Hypertens 2011;13:404-412.

56 Weir MR, Nesbitt SD, Weber M, Shojaee A, Waverczak WF, Qian C: Effects on BP control of amlodipine (AML)/olmesartan medoxomil (OM), with or without hydrochlorothiazide (HCTZ), in black, Hispanic, and Asian patients not controlled by prior antihypertensive monotherapy [abstract 023]. Ethn Dis 2010;20(suppl):S3-S12.

57 Feldman RD, Zou GY, Vandervoort MK, Wong CJ, Nelson SA, Feagan BG: A simplified approach to the treatment of uncomplicated hypertension: a cluster randomized, controlled trial. Hypertension 2009;53:646-653.

58 Bangalore S, Kamalakkannan G, Parkar S, Messerli FH: Fixed-dose combinations improve medication compliance: a meta-analysis. Am J Med 2007;120:713-719. 